\title{
1 Temperature effects on the first three years of soil ecosystem
}

\section{2 development on volcanic ash.}

4 Authors: Ryunosuke Tateno ${ }^{\mathrm{a}^{*}}$, Chikae Tatsumi $^{\mathrm{b}}$, Masataka Nakayama ${ }^{\mathrm{b}}$, Koichi Takahashi $^{\mathrm{c}, \mathrm{d}}$,

5 Dorsaf Kerfahi ${ }^{\mathrm{e}}$, Jonathan Adams $\mathrm{e}^{\mathrm{e}, \mathrm{f} * *}$

6

$7 \quad{ }^{a}$ Field Science Education and Research Center, Kyoto University, Kyoto, Japan.

$8 \quad{ }^{\mathrm{b}}$ Graduate School of Agriculture, Kyoto University, Kyoto, Japan.

$9 \quad{ }^{\mathrm{c}}$ Department of Biology, Faculty of Science, Shinshu University, Matsumoto, Japan.

10 dnstitute of Mountain Science, Shinshu University, Matsumoto, Japan

$11{ }^{\mathrm{e}}$ Department of Biological Sciences, Seoul National University, Seoul, Republic of Korea.

$12{ }^{\mathrm{f}}$ Cranfield Soil and Agrifood Institute, Cranfield University, Cranfield, UK

$14 *$ Corresponding author at:

15 Field Science Education and Research Center, Kyoto University, Kyoto 6068502, Japan.

16 E- mail address: rtateno@kais.kyoto-u.ac.jp (R. Tateno)

**co-corresponding author at: Soil and Agrifood Institute Cranfield University, College Rd,

Cranfield MK43 0AL, Bedfordshire, UK

19 E- mail address: j.m.adams@cranfield.ac.uk, geograph.ecol@gmail.com (J. M. Adams)

Declarations of interest: none 
Little is known of the earliest stages of soil ecosystem development on volcanic ash, and how this process is affected by temperature. We studied the first three years of soil development in a field-based mesocosm experiment, situated in different climates across Japan. Newly fallen, sterilized volcanic ash from the Sakurajima volcano (Kyushu, Japan) was placed into pots and positioned at six locations with mean annual temperatures ranging from $-1.6^{\circ} \mathrm{C}$ to $18.6{ }^{\circ} \mathrm{C}$

Keywords: Carbon accumulation, Nitrification, Primary succession, Temperature gradient, Weathering, Volcanic ash 


\section{Introduction}

The process of soil development in primary successional environments has long been a major theme in ecology and geology (Clements, 1916; Huggett, 1998). As well as studies on soil development in debris flows (Turk et al., 2008, 2009), sand dunes (Lichter, 1998), and glacier forelands (Kaye et al., 2003; Mavris et al., 2010), there has been a considerable amount of work on volcanic primary succession - including both lava flows and volcanic ash deposits (Vitousek et al., 1993; Vitousek and Farrington, 1997; Kato et al., 2005). There have been studies on soil development in ash deposits that at the start of the study were already several years old (Fujimura, et al. 2012, 2016), or older (Ohta et al. 2003; Ibekwe et al. 2007; Zeglin et al., 2016), but there has been little work on the very earliest stages of soil ecosystem development. The first three years or so of soil ecosystem development have barely been studied, perhaps due to the difficulties in gaining access to recent volcanic eruption sites.

It is unclear to what extent the major living components of a soil system - bacteria, archaea and fungi, including important functional groups for biogeochemical processes such as ammonia oxidizers - are present in these earliest stages. Studies on volcanic ash deposits that were already several years old have suggested that early stages in volcanic ash soil development are carried out by chemoautotrophs (King, 2003; Fujimura et al., 2012, 2016). For example, Fujimura et al. $(2012,2016)$ reported the importance of Fe(II)- and $\mathrm{H}_{2}$-oxidizing chemolithotrophs in a 3.5-6.6 years old ash deposit in Miyake Island, Japan, in initiating the accumulation of organic carbon (C) and then contributing to the development of subsequent microbial communities. Furthermore, Freeman et al. (2009) pointed out the importance of photoautotrophic bacteria (cyanobacteria) in high-elevation barren soils. Only later were larger organisms such as bryophytes seen as having a major role (O'Toole and 
Synnott, 1971).

It is also unclear what relationship, if any, the process of soil ecosystem development shows to climate - especially temperature. Temperature is seen as a major controlling factor in ecosystem establishment or recovery (Pastor and Post,1986; Vitousek and Farrington, 1997) as well as pedogenesis (Tsai et al., 2010), but it is unclear how early in the process it becomes important. In this study we were interested in experimentally comparing the effect of temperature on soil ecosystem development from volcanic ash, over the first three years of primary succession. This study was a follow-on from Kerfahi et al. (2017), which discussed the first two years of experimental soil ecosystem development. As we will report here, a pattern was obtained when Year 3 was added to the dataset, with implications for understanding the processes of ecosystem establishment on volcanic ash.

Furthermore, we report here on the inorganic nitrogen $(\mathrm{N})$ dynamics at very early stage of soil development. Nitrogen is not normally present in parent materials such as rock, lava and volcanic ash in certain kinds of metasedimentary and metavolcanic rocks (Holloway et al., 1998). $\mathrm{N}$ deposition from the atmosphere is thought to be the primary source in the earliest stages of microbial community development on volcanic ash, while microbial $\mathrm{N}$ fixation eventually becomes more important.

Our main working hypothesis here was that there would be a temperature effect on the rate of soil ecosystem development (organic $\mathrm{C}$, organic $\mathrm{N}$, inorganic $\mathrm{N}$, abundance of each of the major microbial groups) would become apparent by Year 3 (36 months) of the experiment. Given the large range of climates studied in this experiment, it was surprising to us that no strong temperature effect on $\mathrm{C}, \mathrm{N}$ or microbial biomass emerged in the first two years to 24 months (Kerfahi et al., 2017). We anticipated that as the soil ecosystem developed, including development of a bryophyte cover, this effect would eventually show itself more clearly because of the temperature sensitivity of plant growth and metabolism in producing 
exudates, dead organic material, etc. that would enrich the soil in C and N. So far, there has been little evaluation of the effect of temperature on the earliest stages of ecosystem development on volcanic substrates, under standardized conditions. While a strong temperature effect would certainly be expected on basic biological and ecological principles, it is important to test such assumptions if ecology is to be rigorously based.

\section{Materials and methods}

\subsection{Source of the volcanic ash}

Mt. Sakurajima $\left(31^{\circ} 35^{\prime} \mathrm{N}, 132^{\circ} 39^{\prime} \mathrm{E}\right.$, height $\left.1,117 \mathrm{~m}\right)$ is an active volcano located in southern Kyushu Island, Japan. Mt. Sakurajima is situated in the Aira caldera created by catastrophic eruption of around 29,000 years BP (Kobayashi et al., 2013). Large eruptions have periodically occurred since then, interspersed with less active phases. In the last thousand years, three large eruptions occurred in the Bunmei era (1471-1476), An-ei era (1779-1782), and Taisho era (1914-1915) (Biass et al., 2017) - mainly involving lava flowing from upper parts of the volcano and covering parts of the lower slopes. Since 2006, a new phase and different type of volcanic activity started, involving small explosions and ash deposition over the surrounding slopes over the volcano. These have become more active over time (Iguchi et al., 2013), and presently thousands of small eruptions occur annually (Miwa et al., 2013). The volcanic ash of Mt. Sakurajima is characterized as slightly acidic, of relatively low redox potential, and enriched in ions such as $\mathrm{Si}, \mathrm{Na}, \mathrm{Cl}$, and $\mathrm{SO}_{4}$ (Kawano and Tomita, 2001). Detail of mineral composition of volcanic ash were summarized in Hillman et al. (2012) and Miwa et al. (2013). 


\subsection{Experimental sites}

Six experimental sites were used to position pots of volcanic ash in trays. Six locations across Japan whose mean annual temperature ranged from -2.6 to $18.6^{\circ} \mathrm{C}$ (Table 1). We used recently deposited ash from Mt. Sakurajima for the experimental pot microcosms, as described below.

i) The Sakurajima site (SJ) is in the warm temperate zone of southern Japan, with a mean annual temperature of $18.6^{\circ} \mathrm{C}(1981-2010)$ and a mean annual precipitation of $2265.7 \mathrm{~mm}(1981-2010)$ according to Kagoshima Meteorological Station, Japan $\left(31^{\circ} 33^{\prime} \mathrm{N}\right.$, $130^{\circ} 33^{\prime} \mathrm{E}, 4.0 \mathrm{~m}$ a.sl). The areas sampled were on the lower slopes of the volcano, around 25-50 m above sea level. The site was situated in an open area in the native pine scrub.

ii) The Takakuma site (TK) is in a warm temperate forest site in the surrounding hills near the Sakurajima Volcano, in the Takakuma Experimental Forest of Kagoshima University, southern Kyushu, Japan $\left(31^{\circ} 31^{\prime} \mathrm{N}, 132^{\circ} 46^{\prime} \mathrm{E}, 538 \mathrm{~m}\right.$ a.s.l.). The site is about $10 \mathrm{~km}$ from the crater of Sakurajima with mean annual precipitation is $3410 \mathrm{~mm}$ and a mean annual temperature of $14.0^{\circ} \mathrm{C}(1999-2004)$. The site was situated in an open area by a forest road.

iii) The Kyoto site (KY) is in a warm temperate forest site about $600 \mathrm{~km}$ northeast of Sakurajima at Kamigamo Experimental Station, Kyoto University near Kyoto City, Japan $\left(35^{\circ} 04^{\prime} \mathrm{N}, 135^{\circ} 46^{\prime} \mathrm{E}, 140 \mathrm{~m}\right.$ a.s.1.). Mean annual temperature is $14.6^{\circ} \mathrm{C}$ and annual precipitation is 1,538.6 mm (Kamigamo Experimental Station in 1981-2010). The samples were positioned on an open lawn next to the site weather station. iv, v, vi) Three sites were set at different elevations on Mt. Norikura (summit $3026 \mathrm{~m}$ a.s.l.) in central Japan, located $800 \mathrm{~km}$ northeast of Sakurajima. The elevations of the three experimental sites on Norikura were $650 \mathrm{~m}, 1450 \mathrm{~m}$ and $2800 \mathrm{~m}$ a.s.l. (described here as NK-650m, NK-1450m, and NK-2800m). There were no nearby meteorological stations of 
each site for Norikura, but we calculated MAT based on the nearest meteorological stations on the lower slopes and near summit of Mt. Norikura. Assuming a mean lapse rate is $0.6^{\circ} \mathrm{C} / 100 \mathrm{~m}$, MAT of NK-650 $\mathrm{m} 1450 \mathrm{~m}$ and $2800 \mathrm{~m}$ can be calculated $12.1{ }^{\circ} \mathrm{C}, 7{ }^{\circ} \mathrm{C}$ and $-1.6{ }^{\circ} \mathrm{C}$, respectively (Kerfahi et al., 2017).

For comparison of $\mathrm{C}$ and $\mathrm{N}$ contents of mature developed soils in Japan with the volcanic ash in the experimental pots at weight basis $\left(\mathrm{g} \mathrm{kg}^{-1}\right)$, we used the published data set from 39 sites of well-developed vegetated soils throughout the Japanese archipelago covering $44^{\circ} 20^{\prime} \mathrm{N}$ to $26^{\circ} 50^{\prime} \mathrm{N}$ (Urakawa et al. 2015).

\subsection{Setting up in-situ incubation experiment}

We collected newly fallen volcanic ash on plastic sheeting in an open space (an unused parking lot) near the Sakurajima volcano, over a period of several weeks on March 2012. The freshly accumulated ash was removed and stored every week. The freshly accumulated ash samples were sieved at $2 \mathrm{~mm}$ mesh screen to remove large particles before use. The ash was sterilized by heating in portions to $200{ }^{\circ} \mathrm{C}$ in a dry oven for $1 \mathrm{~h}$. The ash was handled with sterile gloves.

We put $200 \mathrm{~g}$ portions of the dried ash in poly-vinyl chloride (PVC) columns (67 $\mathrm{mm}$ in internal diameter and $150 \mathrm{~cm}^{3}$ in internal volume) with a plastic fine nylon mesh underneath, to avoiding the ash from falling out but allowing water drainage. For estimating leaching of anions and cations from ash columns, we modified the resin core method (Binkley et al., 1986; Shibata et al., 2011; Urakawa et al., 2014). We attached PVC columns (internal diameter is same as ash column) filled with $50 \mathrm{~g}$ ion exchange resin (Amberlite MB-1; Organo, Japan) and sealed the base of the pot by nylon mesh. The combined ash and resin cores were connected tightly using vinyl tape. We put 
15 pots with 5 replicates for each year of sampling in each site. Pots were placed together in a plastic basket on corrugated plastic plates to allow drainage. The whole basket was covered with a $1 \mathrm{~mm}$ white nylon mesh net to exclude windblown materials, seeds, animals, excessively hard rain and extreme heat in direct sunlight. The $1 \mathrm{~mm}$ pore size was intended to be large enough to allow microbes and bryophyte propagules to enter. At each site, the tray was located in a flat open area in full sun.

We set sample trays at each site in late June or early July 2012. After one, two and three years (12, 24 and 36 months), we randomly took five replicate pots from each site for sampling. For each sample pot, the surface $2 \mathrm{~cm}$ of the ash and remaining ash beneath it were taken separately, for DNA extraction and chemical analysis using a sterilized spatula. We also collected the ion exchange resin from beneath each pot, for chemical analysis of captured ions. The samples were transported to the laboratory at $4{ }^{\circ} \mathrm{C}$ and any organic debris removed by sterilized spatula and tweezers. Samples were then frozen at $-20{ }^{\circ} \mathrm{C}$ for further DNA extraction and inorganic $\mathrm{N}\left(\mathrm{NH}_{4}{ }^{+}-\mathrm{N}\right.$ and $\left.\mathrm{NO}_{3}{ }^{-}-\mathrm{N}\right)$ extraction, and remaining ash samples were dried at $105{ }^{\circ} \mathrm{C}$ for further chemical analyses. DNA extraction and soil analysis were carried out as detailed below. Details of the experiment were previously reported in Kerfahi et al. (2017).

\subsection{Chemical measurements}

Extraction and measurement of the $\mathrm{NH}_{4}{ }^{+}-\mathrm{N}$ and $\mathrm{NO}_{3}{ }^{-}-\mathrm{N}$ concentrations followed Urakawa et al. (2014) with some modifications. Briefly, a $5 \mathrm{~g}$ subsample of each soil sample was extracted in $50 \mathrm{ml}$ of $2 \mathrm{M} \mathrm{KCl}$ and filtered to determine the $\mathrm{NH}_{4}{ }^{+}-\mathrm{N}$ and $\mathrm{NO}_{3}{ }^{-} \mathrm{N}$ concentrations. Briefly a $5 \mathrm{~g}$ sample of the ion exchange resin was extracted in $50 \mathrm{ml}$ of $1 \mathrm{M}$ $\mathrm{KCl}$ twice. Also, $\mathrm{NH}_{4}{ }^{+}-\mathrm{N}$ and $\mathrm{NO}_{3}{ }^{-}-\mathrm{N}$ concentrations in ash and ion exchange resin extracts 
were measured colorimetrically.

Ash samples were dried to a constant weight at $105^{\circ} \mathrm{C}$ and then weighed. Total $\mathrm{C}$ and $\mathrm{N}$ concentration of ash samples were determined using an NC analyzer (NC-900; Shimadzu, Kyoto, Japan). We measured $\mathrm{pH}$ of ash samples using $\mathrm{pH}$ meters (D-51, Horiba, Kyoto, Japan) after extraction from $10 \mathrm{~g}$ of dry ash with $25 \mathrm{ml}$ of ion exchange water.

\subsection{DNA extraction and Quantitative PCR analysis ( $q P C R)$}

DNA was extracted from about $0.3 \mathrm{~g}$ volcanic ash samples using the MoBio Powersoil DNA Isolation Kit (MoBio, Carlsbad, CA, USA) according to the manufacturer's instructions and were stored in a freezer at $-20{ }^{\circ} \mathrm{C}$. We quantified the gene abundance of bacterial 16S rRNA, archaeal 16S rRNA, fungal ITS, ammonium-oxidizing bacterial amoA, and ammonium-oxidizing archaeal amoA, real-time quantitative polymerase chain reaction (qPCR) was performed using the Light Cycler 96 (Roche Diagnostics K.K., Mannheim, Germany). Bacterial 16S rRNA, archaeal 16S rRNA, fungal ITS region, ammonium-oxidizing bacterial $a m o A$, and ammonium-oxidizing archaeal $a m o A$ were determined using the universal primer sets, 338f (Amann et al., 1990)/518r (Muyzer et al., 1993), 109f (Großkopf et al., 1998)/344r (Raskin et al., 1994), ITS1F_KYO2 /ITS2_KYO2 (Toju et al., 2012), amoA 1F/amoA 2R (Rotthauwe et al., 1997), and CrenamoA 23F/CrenamoA 616R (Tourna et al., 2008), respectively. The qPCR was performed in $10 \mu \mathrm{L}$ of final volume containing $5 \mu \mathrm{L}$ master mix $2 \mathrm{x}$ from the Faster Essential DNA Green Master Kit (Roche Diagnostics), $1.5 \mu \mathrm{L}$ of PCR grade $\mathrm{H}_{2} \mathrm{O}$ in the kit, $0.5 \mu \mathrm{L}$ each of forward and reverse primers $(10 \mu \mathrm{M})$, and $2.5 \mu \mathrm{L}$ of template DNA (1/10). The conditions of reaction for bacterial 16S rRNA, archaeal 16S rRNA and fungal ITS genes were as follows: an initial denaturation at $95^{\circ} \mathrm{C}$ for $10 \mathrm{~min}$, then more than 


\section{1}

30 cycles of $95^{\circ} \mathrm{C}$ for $1 \mathrm{~min}, 53^{\circ} \mathrm{C}$ for $30 \mathrm{~s}$, and $72^{\circ} \mathrm{C}$ for $1 \mathrm{~min}$ (Fierer and Jackson, 2005).

The conditions of reaction for the bacterial $a m o A$ gene were as follows: an initial denaturation at $95^{\circ} \mathrm{C}$ for $10 \mathrm{~min}$, followed by more than 35 cycles of $95^{\circ} \mathrm{C}$ for $30 \mathrm{~s}, 55^{\circ} \mathrm{C}$ for $30 \mathrm{~s}$, and $72^{\circ} \mathrm{C}$ for $30 \mathrm{~s}$, followed, with the annealing temperature adjusted to $55^{\circ} \mathrm{C}$ (Okano et al., 2004). All of the assays were conducted melting curve analysis. The DNA quantity in the standard clone plasmid for each gene was determined using a Qubit 2.0 Fluorometer (Thermo Fisher Scientific, Waltham, MA, USA). Relative quantification of genes was conducted as serial dilution standards and calculated using Light Cycler 96 Software version 1.0 (Roche Diagnostics).

\subsection{Bryophyte cover}

We estimated visually percentage bryophyte cover on the tops of the pots using photographs. For the three Norikura sites at the 12 months and 24 months stage there was no observed bryophyte cover at the time of sampling. We divided each photograph into eight portions radially, and estimated percentage of bryophyte cover for each $12.5 \%$ interval. We divided the pot surface into 24 portions if percentage of cover were less than $12.5 \%$ or more than $87.5 \%$.

\subsection{Statistical analysis}

We tested three models (linear, quadratic, and exponential) to describe relationships between MAT and ash $\mathrm{C}$ and $\mathrm{N}$ accumulation rates. Model selection was carried out based on adjusted $R^{2}$ and root mean square error (RMSE). Significance level was defined as $<5 \%$. All statistical analyses were conducted using IBM SPSS Statistics (IBM SPSS 22.0, IBM 
Corp., Armonk, NY, USA).

\section{Results}

\subsection{Changes in soil organic matter accumulation}

250

Both $\mathrm{C}$ and $\mathrm{N}$ accumulation rate and content were not significantly correlated with MAT for the 12 month and 24 months stage, except for $\mathrm{N}$ at 24 months stage (Fig. 1). However, by the 36 month stage $\mathrm{C}$ and $\mathrm{N}$ accumulation rate and total $\mathrm{C}$ and $\mathrm{N}$ increased exponentially with MAT (Fig. 1), in the top $2 \mathrm{~cm}$. These patterns were more obvious in the upper $2 \mathrm{~cm}$ layer, where $\mathrm{C}$ and $\mathrm{N}$ accumulation rates were much faster than in the lower layer of ash (Fig. S1 and S2).

\subsection{Bryophyte cover}

Percentage of bryophyte cover was summarized in Table 2. At the 12 month stage, there was no bryophyte cover in almost all of the pots. Only a few very small bryophyte plants (Polytrichum sp.) were observed in SJ and KY sites by this stage. By 24 months, percentage bryophyte cover had increased in the warmest three sites, but still no bryophyte cover was observed in cooler three Norikura sites. An incomplete surface covering of bryophytes (Polytrichum sp. and Plagiochila sp.), small cyanobacterial mats (Nostoc sp.) and small gray foliose lichens (tentatively identified as Parmelia sp.) were observed. By 36 months, percentage bryophyte cover had further increased in warmer sites (Table 2 and Fig. S3). In the two warmest sites, TK and SJ, the percentage bryophyte cover exceeded more than $90 \%$, while coolest two sites still had no apparent bryophyte cover. Almost complete surface 
covering of bryophytes (Polytrichum sp. and Plagiochila sp.) in SJ and TK, and incomplete but substantial covering of (Polytrichum sp.) in KY, and small cover by bryophytes (tentatively identified as Bryum argentum) and lichens (Parmelia sp.) in NK-650 m were observed. There were significant correlations between percentage bryophyte cover and content of $\mathrm{C}$ and $\mathrm{N}$ (Fig. 2).

\subsection{Inorganic $\mathrm{N}$ dynamics and $\mathrm{pH}$ change}

Total pool size of $\mathrm{NO}_{3}{ }^{-} \mathrm{N}, \mathrm{NH}_{4}{ }^{+}-\mathrm{N}$, inorganic $\mathrm{N}\left(\mathrm{NO}_{3}{ }^{-} \mathrm{N}+\mathrm{NH}_{4}{ }^{+}-\mathrm{N}\right)$ did not show clear patterns in relation to MAT and age of ash except for $\mathrm{NH}_{4}{ }^{+}-\mathrm{N}$ and inorganic $\mathrm{N}$ of 24 months stage (Fig. 3). Pool size of $\mathrm{NO}_{3}{ }^{-}-\mathrm{N}$ was far less than $\mathrm{NH}_{4}{ }^{+}-\mathrm{N}$ pool, while $\mathrm{NH}_{4}{ }^{+}-\mathrm{N}$ were constantly existed even in early soil development (Fig. 3).

Percentage of inorganic $\mathrm{N}$ out of total $\mathrm{N}$ ranged from $11.6 \pm 3.5$ to $22.3 \pm 6.5 \%$ after 12 months and did not show clear patterns in relation to MAT (Fig. 4). Percentage of inorganic $\mathrm{N}$ to total $\mathrm{N}$ ranged from $7.1 \pm 1.4$ to $14.2 \pm 2.5 \%$ after 24 months and $4.2 \pm 10.9$ to $23.1 \pm 4.4 \%$ after 36 months stage. There were significant negative correlations between percentage of inorganic $\mathrm{N}$ to total $\mathrm{N}$ and MAT at the 24 months and 36 months stages.

Leaching of $\mathrm{NO}_{3}{ }^{-}-\mathrm{N}, \mathrm{NH}_{4}{ }^{+}-\mathrm{N}$, and inorganic $\mathrm{N}\left(\mathrm{NH}_{4}{ }^{+}-\mathrm{N}+\mathrm{NO}_{3}{ }^{-}-\mathrm{N}\right)$ tended to increase with MAT, but decreased again in the warmest site, SJ (Fig. 5). While leaching of $\mathrm{NO}_{3}{ }^{-}-\mathrm{N}, \mathrm{NH}_{4}{ }^{+}-\mathrm{N}$, and inorganic $\mathrm{N}\left(\mathrm{NO}_{3}{ }^{-}-\mathrm{N}+\mathrm{NH}_{4}{ }^{+}-\mathrm{N}\right)$ did not show any significant relationship with MAT (Fig. 5). The pattern of $\mathrm{NO}_{3}{ }^{-}-\mathrm{N}$ leaching was comparable to $\mathrm{NH}_{4}{ }^{+}-\mathrm{N}$ leaching despite the pool size of $\mathrm{NO}_{3}{ }^{-}-\mathrm{N}$ being far less than the $\mathrm{NH}_{4}{ }^{+}-\mathrm{N}$ pool (Fig. 5).

The $\mathrm{pH}$ of ash across sites ranged from $4.18 \pm 0.09$ to $6.10 \pm 0.09,4.66 \pm 0.08$ to $6.28 \pm 0.03$, and $4.06 \pm 0.93$ to $6.47 \pm 0.14$ after 12,24 , and 36 months stages, respectively 
(Table S1). The $\mathrm{pH}$ of ash tended to decreased with MAT however not significantly (Table

S1). Changes in $\mathrm{pH}$ of the ash did not show any consistent pattern across the sites (Table S1).

\subsection{Microbial gene abundance}

Bacterial and archaeal 16S rRNA gene abundance and fungal ITS gene abundance did not show clear patterns in relation to the time stage of the experiment except for some exceptions, but in all cases tended to be higher in upper $2 \mathrm{~cm}$ layer of the pot (Fig. 6).

Bacterial and archaeal $a m o A$ gene abundance also did not show any significant clear patterns in relation to time stage, while tending to be higher in upper $2 \mathrm{~cm}$ (Fig. 7). Abundance of each of these genes increased with MAT, but decreased again in the warmest site SJ for some, such as fungal ITS and the $a m o A$ gene of bacteria and archaea (Fig. 6-7).

\section{Discussion}

\subsection{How much soil ecosystem development can occur in 3 years?}

In this volcanic ash system, we found a measurable presence of bacteria, archaea and fungi, and archaeal/bacterial ammonia oxidizers, in the first three years of the experiment, and a build up of organic C and N. A previous study (Kerfahi et al., 2017) from the same experiment found that many common soil bacterial groups were already present by 24 months, although there was a high proportion of 'unclassified' bacteria - possibility including novel groups peculiar to this environment. However, the overall concentration of $\mathrm{C}$ and $\mathrm{N}$ in ash samples after 36 months were up to $3.0 \mathrm{gC} \mathrm{kg}^{-1}$ for $\mathrm{C}$ and $0.18 \mathrm{gN} \mathrm{kg}^{-1}$ for $\mathrm{N}$, which were still several orders of magnitude less than fully developed forest soils across Japan, which 
averaged 92.4, 51.2, $31.9 \mathrm{gC} \mathrm{kg}^{-1}$ in $0-10 \mathrm{~cm}, 10-30 \mathrm{~cm}$ and $30-50 \mathrm{~cm}$, respectively for $\mathrm{C}$ and from $5.4,2.9,1.9 \mathrm{gN} \mathrm{kg}^{-1}$ in $0-10 \mathrm{~cm}, 10-30 \mathrm{~cm}$ and $30-50 \mathrm{~cm}$, respectively for $\mathrm{N}$ (Urakawa et al. 2015, Fig. S4). Furthermore, bacteria, archaea, and ammonia oxidizer abundance of ash samples ranged $10^{6}-10^{8}, 10^{4}-10^{6}$, and $10^{2}-10^{5}$ gene copy per gram soils (Fig. 6, 7) which were several orders of magnitude less than in developed temperate forest soils reported previously, i.e. $10^{7}-10^{10}, 10^{7}-10^{9}$, and $10^{5}-10^{7}$ gene copy per gram soils for bacteria, archaea, and ammonia oxidizer abundance, respectively (Kemnitz et al., 2007; Isobe et al., 2015, 2018).

While it was not possible to quantify the main source of $\mathrm{N}$ entering the system in this study sites, reported total $\mathrm{N}$ deposition across Japan ranged from 0.30 to $1.65 \mathrm{~g} \mathrm{~m}^{-2} \mathrm{y}^{-1}$ (Chiwa et al., 2015; Ban et al. 2016), and then either accumulating in the soil, or being leached and captured in the resin under the pots. In early primary successional systems, the main source is biological $\mathrm{N}$ fixation by cyanolichen (Crews et al., 2001). The fluxes of $\mathrm{N}$ in the first 12 months of the experiment are more likely to reflect the background of atmospheric deposition, and represent a baseline from which fluxes increase over time during the experiment. However, the observed fluxes to the resin are complicated by the likely capture and build up of $\mathrm{N}$ in the bryophyte layer (a reservoir which was not included in this study), and its sequestration in the soil total $\mathrm{N}$ pool, preventing $\mathrm{N}$ from leaching out of the pot. By the 36 months stage, some of the warmer climate samples had less $\mathrm{N}$ flux to the resin, possibly reflecting greater $\mathrm{N}$ sequestration into growing bryophyte biomass. This is a sign of the ecosystem becoming more 'closed' and efficient during succession (Odum, 1966).

In our sites the amount of $\mathrm{NO}_{3}{ }^{-}-\mathrm{N}$ leaching was similar to the rate of $\mathrm{NH}_{4}{ }^{+}-\mathrm{N}$ leaching from ash pots, which accorded with the pattern observed in total $\mathrm{N}$ deposition across Japan (Chiwa et al., 2015; Ban et al. 2016). Certain part of N deposition may directly reach out from our experimental pots. As another possible explanation, ammonia oxidizing bacteria and archaea were always present in pots, suggesting the importance of ammonia oxidizing 
activity in early soil ecosystem development and source of $\mathrm{NO}_{3}{ }^{-}-\mathrm{N}$ leaching from pots would derived from ammonia oxidizers. By contrast, ammonia oxidation and methane oxidation were found to be negligible at most sites in Hawaian lava flow successional series from about 18 to 300 years old (King, 2003). Soil physical properties of ash deposits could be preferable environments for ammonia oxidizers compared to those of lava flow, and thus ammonia oxidizer could be important microbes in early stage of ash soil development.

The proportion of inorganic $\mathrm{N}$ relative to total $\mathrm{N}$ decreased with increasing MAT, as well as with time, an indication of the increasing importance of organic $\mathrm{N}$ in the developing soil ecosystem. This organic $\mathrm{N}$ would be important source for utilization by microbes as well as external source such as deposition. Photosynthetic microbes and $\mathrm{N}$ fixing microbes may also be important in the early stages of soil development (Crews et al. 2001). Indeed, Kerfahi et al. (2017) reported that the relative abundance of Cyanobacteria, Chloroflexi and Firmicutes, which include photosynthetic and $\mathrm{N}$ fixing microbes, were significantly higher in the same volcanic ash at the 24 months stage than in forest soils. While the energy costs for $\mathrm{N}$ fixing microbes to fix $\mathrm{N}$ are far higher than to assimilate $\mathrm{N}$ from ammonium, $\mathrm{N}$ fixation is affected by C and N availability of environments (Bottomley and Myrold 2007, Reed et al. 2011). In early stages of soil development, $\mathrm{N}$ fixation might be limited more by $\mathrm{C}$ availability than $\mathrm{N}$ availability. Further potential studies to investigate this may include metagenome and metatranscriptome analyses.

It is likely that microbes in the soil play an important role in the transformation of the original silicate minerals in the ash to clays and other minerals, releasing metal ions (e.g. $\mathrm{Na}, \mathrm{Mg}, \mathrm{K}$, and $\mathrm{Ca}$ ) that can be utilized by the developing plant cover (Kawano and Tomita 2001). The importance of microbes in this process was shown in an earlier laboratory mesocosm study of Sakurajima volcanic ash, where a sterile system was compared to a non-sterile one with soil microbes present (Bennett et al. 2001; Kawano and Tomita 2001). 

development of the soil ecosystem, but those of our treatments with abundant bryophyte cover showed evidence of accelerated buildup of $\mathrm{N}$ and $\mathrm{C}$ (Fig. 2). The role of bryophytes in soil development in primary succession has been considered previously (O'Toole and Synnott, 1971; Brown and Bates,1990). While bryophytes do not have a root system as such, they have hair-like structures (rhizoids) that penetrate the soil, and their turnover supply $\mathrm{C}$ and $\mathrm{N}$ to the soil, and dead parts of the photosynthetic thallus are appressed against the soil surface or fall to it. It is clear that most of the enrichment in $\mathrm{C}$ and $\mathrm{N}$ is in the top $2 \mathrm{~cm}$ layer of our experimental pots, which has a more rapid accumulation of these two elements - likely due to the proximity to the bryophyte sources of photosynthetically fixed material. Bryophytes can survive by taking up $\mathrm{N}$ as well as minerals from deposition in rain and by dust, but mineral availability from substrate is thought to be important to establishment (O'Tool \& Synnott,1971; Brown and Bates, 1990; Bates and Farmer, 1990). It would be interesting to investigate whether potentially mutualistic fungi were present in the top later of the developing soil - although there is no experimental evidence for the transfer of photosynthates and nutrients between AM fungi and bryophytes (Davey and Curah, 2006). Plant establishment is an important factor accelerating organic matter accumulation by litterfall, dead root tissues and root exudate, and thus affecting soil microbes (Zak, et al., 2003; Wardle, et al., 2004). It is possible that once a complete bryophyte cover is established, the moist surface conditions and possibly the exudates from the plants, encourage biotic and abiotic weathering that provides further mineral nutrients for the bryophyte community. This then is a positive feedback dependent on development of a bryophyte cover. However, the $\mathrm{pH}$ of the ash is apparently not connected to the bryophyte cover as the decrease in $\mathrm{pH}$ was already seen after one year when the bryophyte cover was still very low. Apparently precipitation, MAT and possibly $\mathrm{N}$ deposition are the main factors influencing the $\mathrm{pH}$ at 
these early stages of soil development.

The overall picture from this study is that within three years starting from sterile volcanic ash, in temperate and warm temperate climates at least, a soil ecosystem can build up with a surface layer of plant primary producers (bryophytes), significant accumulation of soil $\mathrm{C}$ and $\mathrm{N}$, with ammonia oxidation occurring. In the warm temperate sites, the system was beginning to show signs of becoming closed, with reduced leaching of $\mathrm{N}$ out of the system. Bryophytes are known to be a strong sink of atmospherically deposited N (Binkley and Graham, 1981, Weber and Van Cleve, 1984). Nevertheless, in all the sites the amount of C and $\mathrm{N}$ after three years is still much less than in mature forest soils, such as would be found under forest in Japan (Fig. S4).

It is important to bear in mind that the mesocosm system we used might either accelerate or decelerate the speed of soil ecosystem development on volcanic ash. The gauze covered pots we used might tend to avoid extremes of temperature, and retain humidity. We found that generally, in all sites, the air temperature within the gauze-covered trays next to the pots was about $1{ }^{\circ} \mathrm{C}$ warmer than the ambient in sunny weather - though no different in other weather conditions (Kerfahi et al. 2017). This raised temperature may tend to accelerate soil development - although it should affect all sites to a similar extent. On the other hand, it is possible that with the gauze covering excluding windblown seeds, the lack of vascular plants rooting into the ash might have impeded the process of ecosystem development. It has been suggested that vascular plant roots and their associated biota play an important role in chemical weathering (Cochran and Berner, 1996; Landeweert et al., 2001).

\subsection{How does temperature affect the rate of soil ecosystem development?}


only a weakly significant or non-significant effects of temperature on the soil attributes we measured (Fig. 1). However, at the 3 years stage (36 months) a clear effect of temperature emerged, at least in terms of $\mathrm{C}$ and $\mathrm{N}$ (Fig. 1c, f), and only in the top $2 \mathrm{~cm}$ layer of the pots. It is noticeable that the acceleration of $\mathrm{C}$ and $\mathrm{N}$ accumulation in the soils of the warmest sites is associated with an increase in bryophyte cover. This change further emphasizes the potential importance of bryophytes in the development of this ecosystem - acting as a source of C and $\mathrm{N}$ to the developing soil.

The relationship to bryophyte cover may be tentatively seen as evidence for a positive feedback effect between soil ecosystem development and bryophyte vegetation cover, with accelerated plant growth being an important driver at higher temperature. It appears that in the warmer three sites in our series, soil ecosystem development is held back until bryophyte cover develops - at which point there is a rapid increase in $\mathrm{C}$ and $\mathrm{N}$, presumably due to dead material arriving in the upper soil from the bryophyte plants. The accumulation of $\mathrm{C}$ and $\mathrm{N}$ itself can be expected to promote bryophyte growth, by providing a more moisture retentive and nutrient rich soil, and accelerating chemical weathering of the ash although there was no direct measurement of chemical weathering indicators in this study.

\subsection{Microbial abundance did not increase with age or temperature.}

We had anticipated that the copy number of microbial genes - an indicator of microbial population density - would increase greatly during the 3 years experiment. Surprisingly, there was no significant time trend in any of the indicators (16S rRNA genes of bacteria, archaea and fungi, and archaeal and bacterial amoA genes). Nor was there any tendency for the warmer climate stations to have greater copy numbers, even though $\mathrm{C}$ and $\mathrm{N}$ accumulation in the soil was clearly greater in the warmer sites by 36 months (Fig 1c, f). The microbial abundance may reflect an active population which processes new 
input of organic material to the soil from bryophytes and other primary producers such as cyanobacteria. However, despite the throughput of material - which leads to the organic $\mathrm{C}$ and $\mathrm{N}$ building up in the ash pot soils - microbial abundance does not appear to accumulate. In mature forest soils, by contrast, microbial abundance is much greater (Fig. S5), so on the longer timescale there is clearly some overall relation to age of the soil.

\section{Conclusion}

Our study provides a rare first glimpse and the very earliest stages of soil ecosystem development on volcanic ash. Following through volcanic ash mesocosms for their first three years reveals a temperature- and time-dependent component, with accelerated ecosystem development once a complete bryophyte cover is established. In warmer climates, this cover establishes early, possibly initiating a feedback between soil development and bryophyte coverage.

It would be interesting to follow up this study with further analysis of the same soils - measurement of conversion of silicates to clays as an indicator of weathering, Ca mineral fluxes, and sequencing of bacterial communities and metagenomes for Year 3. A longer term study, following the ash soil over 20 years or more of ecosystem development, would also be interesting to the understanding of ecosystem development in volcanic landscapes.

\section{Acknowledgements}

We would like to thank Takakuma experimental forest of Kagoshima University, Kamigamo Experimental Station of Kyoto University for support of site managements and 

the members of Laboratory of Silviculture, Faculty of Agriculture, Kagoshima University and Laboratory of Plant Ecology, Faculty of Science, Shinshu University for fieldworks. This study was partly supported by a grant of $(11213205,20780120$, and 26292085) from the

471 Japan Society for the Promotion of Science. This study was also supported by from Kyoto 472 University Young Scholars Oversea Visit Program, the John Mung Program. All authors have no conflicts of interest to declare. 


\section{References}

Amann, R.I., Blinder, B.J., Olson, R.J., Chisholm, S.W., Devereux, R., Stahl, D.A., 1990. Combination of $16 \mathrm{~S}$ rRNA-targeted oligonucleotide probes with flow cytometry for analyzing mixed microbial populations. Appl. Environ. Microbiol. 56, 1919-1925.

Ban, S., Matsuda, K., Sato, K., Ohizumi, T., 2016. Long-term assessment of nitrogen deposition at remote EANET sites in Japan. Atmos. Environ. 146, 70-78.

Bates, J.W., \& Farmer, A.M., 1990. An experimental study of calcium acquisition and its effects on the calcifuge moss Pleurozium schreberi. Ann. Bot. 65, 87-96.

Bennett, P.C., Rogers, J.R., Choi, W.J., Hiebert, F.K., 2001. Silicates, silicate weathering, and microbial ecology. Geomicrobiol. J., 18, 3-19.

Biass, S., Todde, A., Cioni, R. Pistolesi, M., Geshi, N., Bonadonna, C., 2017. Potential impacts of tephra fallout from a large-scale explosive eruption at Sakurajima volcano, Japan. Bull. Volcanol. 79, 73.

Binkley, D., Graham, R.L., 1981. Biomass, production, and nutrient cycling of mosses in an old-growth Douglas-fir forest. Ecology, 62, 1387-1389.

Binkley, D., Aber, J., Pastor, J., Nadelhoffer, K., 1986. Nitrogen availability in some Wisconsin forest: comparisons of resin bags and on-site incubations. Biol. Fertil. Soils 2, $77-82$.

Brown, D.H., Bates, J.W., 1990. Bryophytes and nutrient cycling. Bot. J. of the Linn. Soc. $104,129-147$.

Chiwa, M., Saito, T., Haga, H., Kato, H., Otsuki, K., Onda, Y., 2015. A nitrogen-saturated plantation of Cryptomeria japonica and Chamaecyparis obtusa in Japan is a large nonpoint nitrogen source. J. Environ. Qual. 44, 1225-1232.

Clements, F.E., 1916. Plant succession: an analysis of the development of vegetation (No. 242). Carnegie Institution of Washington, Washington.

Cochran, M.F., Berner, R.A., 1996. Promotion of chemical weathering by higher plants: field observations on Hawaiian basalts. Chem. Geol. 132, 71-77.

Crews, T.E., Kurina, L.M., Vitousek, P.M., 2001. Organic matter and nitrogen accumulation and nitrogen fixation during early ecosystem development in Hawaii. Biogeochemistry $52,259-279$.

Davey, M.L., Currah, R.S., 2006. Interactions between mosses (Bryophyta) and fungi. Botany 84, 1509-1519. 
Fierer, N., Jackson, J., 2005. Assessment of soil microbial community structure by use of taxon-specific quantitative PCR assays. Appl. Environ. Microbiol. 71, 4117-4120.

Freeman, K.R., Pescador, M.Y., Reed, S.C., Costello, E.K., Robeson, M.S., Schmidt, S.K., 2009. Soil CO2 flux and photoautotrophic community composition in high- elevation,'barren'soil. Environ. Microbiol. 11, 674-686.

Fujimura, R., Sato, Y., Nishizawa, T., Nanba, K., Oshima, K., Hattori, M., Kamijo, T., Ohta, H., 2012. Analysis of early bacterial communities on volcanic deposits on the Island of Miyake (Miyake-jima), Japan: a 6-year study at a fixed site. Microbes Environ. 27:19-29.

Fujimura, R., Kim, S.W., Sato, Y., Oshima, K., Hattori, M., Kamijo, T., Ohta, H., 2016. Unique pioneer microbial communities exposed to volcanic sulfur dioxide. Sci. Reports 6, 19687.

Großkopf, R., Janssen, P.H., Liesack, W., 1998. Diversity and structure of the methanogenic community in anoxic rice paddy soil microcosms as examined by cultivation and direct 16S rRNA gene sequence retrieval. Appl. Environ. Microbiol. 64, 960-969.

Hillman, S.E., Horwell, C.J., Densmore, A.L., Damby, D.E., Fubini, B., Ishimine, Y., Tomatis, M., 2012. Sakurajima volcano: a physico-chemical study of the health consequences of long-term exposure to volcanic ash. Bull. of Volcanol. 74, 913-930.

Holloway, J.M., Dahlgren, R.A., Hansen, B., Casey, W.H., 1998. Contribution of bedrock nitrogen to high nitrate concentrations in stream water. Nature $395,785$.

Huggett, R.J., 1998. Soil chronosequences, soil development, and soil evolution: a critical review. Catena 32, 155-172.

Ibekwe, A.M., Kennedy, A.C., Halvorson, J.J., Yang, C.H., 2007. Characterization of developing microbial communities in Mount St. Helens pyroclastic substrate. Soil Biol. Biochem. 39, 2496-2507.

Iguchi, M., Tameguri, T., Ohta, Y., Ueki, S., Nakao, S., 2013. Characteristics of volcanic activity at Sakurajima volcano's Showa crater during the period 2006 to 2011. Bull. Volcanol. Soc. Jpn. 58, 115-135.

Isobe, K., Ohte, N., Oda, T., Murabayashi, S., Wei, W., Senoo, K., Tokuchi, N., Tateno, R., 2015. Microbial regulation of nitrogen dynamics along the hillslope of a natural forest. Front. Environ. Sci. 2, 63.

Isobe, K., Oka, H., Watanabe, T., Tateno, R., Urakawa, R., Liang, C., Senoo, K., Shibata, H., 2018. High soil microbial activity in the winter season enhances nitrogen cycling in a 
cool-temperate deciduous forest. Soil Biol. Biochem. 124, 90-100.

Kato, T., Kamijo, T., Hatta, T., Tamura, K., Higashi, T., 2005. Initial soil formation processes of volcanogenous Regosols (Scoriacious) from Miyake-jima Island, Japan. Soil Sci. Pl. Nutr. 51:291-301.

Kawano, M., Tomita, K., 2001. Microbial biomineralization in weathered volcanic ash deposit and formation of biogenic minerals by experimental incubation. Am. Mineral. 86, $400-410$

Kaye, J.P., Binkley, D., Rhoades, C., 2003. Stable soil nitrogen accumulation and flexible organic matter stoichiometry during primary floodplain succession. Biogeochemistry 63, $1-22$.

Kerfahi, D., Tateno, R., Takahashi, K., Cho, H., Kim, H., Adams, J.M., 2017. Development of soil bacterial communities in volcanic ash microcosms in a range of climates. Microb. Ecol. 73, 775-790.

King, G.M., 2003. Contributions of atmospheric CO and hydrogen uptake to microbial dynamics on recent Hawaiian volcanic deposits. Appl. Environ. Microbiol. 69:4067-4075.

Kobayashi, T., Miki, D., Sasaki, H., Iguchi, M., Yamamoto, T., Uto, K., 2013. Geological map of Sakurajima volcano, second edition. Geological Survey of Japan, Tsukuba, Japan.

Kemnitz, D., Kolb, S., Conrad, R., 2007. High abundance of Crenarchaeota in a temperate acidic forest soil. FEMS Microb. Ecol. 60, 442-448.

Landeweert, R., Hoffland, E., Finlay, R.D., Kuyper, T.W., van Breemen, N., 2001. Linking plants to rocks: ectomycorrhizal fungi mobilize nutrients from minerals. Trends Ecol. Evol. 16, 248-254.

Lichter, J., 1998. Primary succession and forest development oncoastal Lake Michigan sand dunes. Ecol. Mon. 68, 487-510.

Mavris, C., Egli, M., Plötze, M., Blum, J.D., Mirabella, A., Giaccai, D., Haeberli, W., 2010. Initial stages of weathering and soil formation in the Morteratsch proglacial area (Upper Engadine, Switzerland). Geoderma 155, 359-371.

Miwa, T., Geshi, N., Shinohara, H., 2013. Temporal variation in volcanic ash texture during a vulcanian eruption at the Sakurajima volcano, Japan. J. Volcanol. Geotherm. Res. 260, 80-89.

Muyzer, G., De Waal, E.C., Uitierlinden, A.G., 1993. Profiling of complex microbial 
populations by denaturing gradient gel electrophoresis analysis of polymerase chain reaction-amplified genes coding for 16S rRNA. Appl. Environ. Microbiol. 59, 695-700.

Odum, E.P., 1966. The strategy of ecosystem development. Science 164, 262-270.

Ohta, H., Ogiwara, K., Murakami, E., Takahashi, H., Sekiguchi, M., Koshida, K., Someya, T., Morishima, W., Rondal, J.D., Concepcion, R.N., Yoshida, M. Watanabe, M., 2003. Quinone profiling of bacterial populations developed in the surface layer of volcanic mudflow deposits from Mt. Pinatubo (the Philippines). Soil Biol. Biochem. 35, $1155-1158$.

Okano, Y., Hristova K.R., Leutenegger, C.M., Jackson, L.E., Denison, R.F., Gebreyesus, B., Lebauer, D., Scow K.M., 2004. Application of real-Time PCR to study effects of ammonium on population size of ammonia-oxidizing bacteria in soil. Appl. Environ. Microbiol. 70, 1008-1016.

O'Toole, M.A., Synnott, D.M., 1971. The bryophyte succession on blanket peat following calcium carbonate, nitrogen, phosphorus and potassium fertilizers. J. Ecol. 59, $121-126$.

Pastor, J., Post, W.M., 1986. Influence of climate, soil moisture, and succession on forest carbon and nitrogen cycles. Biogeochemistry 2, 3-27.

Raskin, L., Stromley, J.M., Rittmann, B.E., Stahl, D.A., 1994. Group-specific 16S ribosomal-RNA hybridization probes to describe natural communities of methanogens. Appl. Environ. Microbiol. 60, 1232-1240.

Rotthauwe, J.J.H., Witzel, K.K.P., Liesack, W., 1997. The Ammonia monooxygenase structural gene amoA as a functional marker: molecular fine-scale analysis of natural ammonia-oxidizing populations. Appl. Environ. Microbiol. 63, 4704-4712.

Shibata, H., Urakawa, R., Toda, FurakaH., Inagaki, Y., Tateno, R., Koba, K., Nakanishi, A., Fukuzawa, K., Yamasaki, A., 2011. Changes in nitrogen transformation in forest soil representing the climate gradient of the Japanese archipelago. J. For. Res. 16, 374-385.

Toju, H., Tanabe, A.S., Yamamoto, S., Sato, H., 2012. High-coverage ITS primers for the DNA-based identification of ascomycetes and basidiomycetes in environmental samples. PLoS ONE 7, e40863.

Tourna, M., Freitag, T.E., Nicol, G.W., Prosser, J.I., 2008. Growth, activity and temperature responses of ammonia-oxidizing archaea and bacteria in soil microcosms. Environ. Microbiol. 10, 1357-1364.

Tsai, C.C., Chen, Z.S., Kao, C.I., Ottner, F., Kao, S.J., Zehetner, F., 2010. Pedogenic 
development of volcanic ash soils along a climosequence in Northern Taiwan. Geoderma 156, 48-59.

Turk, J.K., Goforth, B.R., Graham, R.C., Kendrick, K.J., 2008. Soil morphology of a debris flow chronosequence in a coniferous forest, southern California, USA. Geoderma 146, $157-165$

Turk, J.K., Graham, R.C., 2009. Soil carbon and nitrogen accumulation in a forested debris flow chronosequence, California. Soil Sci. Soc. Am. J. 73, 1504-1509.

Urakawa, R., Shibata, H., Kuroiwa, M., Inagaki, Y., Tateno, R., Hishi, T., Fukuzawa, K., Hirai, K., Yoda, H., Oyanagi, N., Nakata, M., Nakanishi, A., Fukushima, K., Enoki, T., Suwa, Y., 2014. Effects of freeze-thaw cycles resulting from winter climate change on soil nitrogen cycling in ten temperate forest ecosystems throughout the Japanese archipelago. Soil Biol. Biochem. 74, 82-94.

Urakawa, R., Ohte, N., Shibata, H., Tateno, R., Hishi, T., Fukushima, K., Inagaki, Y. Hirai, K., Oda, T., Oyanagi, N., Nakata, M., Toda, H., Kenta, T., Fukuzawa, K, Watanabe, T., Tokuchi, N., Nakaji, T., Saigusa, N., Yamao, Y., Nakanishi, A., Enoki T., Ugawa, S., Hayakawa, A., Kotani, A., Kuroiwa, M., Isobe, K., 2015. Biogeochemical nitrogen properties of forest soils in the Japanese archipelago. Ecol. Res. 30, 1-2.

Vitousek, P.M., Walker, L.R., Whiteaker, L.D., Matson, P.A., 1993. Nutrient limitations to plant growth during primary succession in Hawaii Volcanoes National Park. Biogeochemistry 23, 197-215.

Vitousek, P.M., Farrington, H., 1997. Nutrient limitation and soil development: experimental test of a biogeochemical theory. Biogeochemistry 37, 63-75.

Wardle, D.A., Bardgett, R.D., Klironomos, J.N., Setälä, H., Van Der Putten, W.H., Wall, D.H., 2004. Ecological linkages between aboveground and belowground biota. Science 304, 1629-1633.

Weber, M.G., Van Cleve, K., 1984. Nitrogen transformations in feather moss and forest floor layers of interior Alaska black spruce ecosystems. Can. J. For. Res. 14, 278-290.

Zak, D.R., Holmes, W.E., White, D.C., Peacock, A.D., Tilman, D., 2003. Plant diversity, soil microbial communities, and ecosystem function: are there any links? Ecology 84, 2042-2050.

Zeglin, L.H., Wang, B., Waythomas, C., Rainey, F., Talbot, S.L., 2016. Organic matter quantity and source affects microbial community structure and function following volcanic eruption on Kasatochi Island, Alaska. Environ. Microbiol. 18, 146-158. 
Table 1 Mean annual temperature (MAT), mean annual precipitation (MAP), elevation, 640 latitude and longitude of each site.

\begin{tabular}{llllll}
\hline Site Name & MAT $\left({ }^{\circ} \mathrm{C}\right)$ & MAP $(\mathrm{mm})$ & Elevation $(\mathrm{m})$ & $\mathrm{N}$ & $\mathrm{E}$ \\
\hline NK_2800m & -1.6 & Unknown & 2800 & $36^{\circ} 07^{\prime}$ & $137^{\circ} 33^{\prime}$ \\
NK_1450m & 7.0 & 1991 & 1450 & $36^{\circ} 07^{\prime}$ & $137^{\circ} 37^{\prime}$ \\
NK_650m & 12.1 & 1045 & 650 & $36^{\circ} 15^{\prime}$ & $137^{\circ} 57^{\prime}$ \\
KY & 14.6 & 1584 & 140 & $35^{\circ} 04^{\prime}$ & $135^{\circ} 46^{\prime}$ \\
TK & 14.0 & 3410 & 660 & $31^{\circ} 31^{\prime}$ & $130^{\circ} 46^{\prime}$ \\
SJ & 18.6 & 2266 & 3 & $31^{\circ} 35^{\prime}$ & $130^{\circ} 35^{\prime}$ \\
\hline
\end{tabular}


Table 2 Bryophyte cover (\%) of ash pots after 1-year, 2, and 3 years of experiment. 643 Mean \pm SD $(\mathrm{n}=5)$.

\begin{tabular}{llll}
\hline Site Name & 1-year & 2-year & 3-year \\
\hline NK_2800m & $0.0(0.0)$ & $0.0(0.0)$ & $0.0(0.0)$ \\
NK_1450m & $0.0(0.0)$ & $0.0(0.0)$ & $0.0(0.0)$ \\
NK_650m & $0.0(0.0)$ & $0.0(0.0)$ & $13.3(14.0)$ \\
KY & $1.9(1.7)$ & $11.3(14.9)$ & $38.8(28.8)$ \\
TK & $1.3(2.8)$ & $10.6(22.1)$ & $92.5(4.7)$ \\
SJ & $0.0(0.0)$ & $9.4(4.4)$ & $96.9(0)$ \\
\hline
\end{tabular}




\section{Figure captions}

Fig. $1 \mathrm{C}$ and $\mathrm{N}$ accumulation rates of ash pots for (a, d) 1-year, (b, e) 2, and (c, f) 3 years of experiment in relation to MAT. We tested three models (linear, quadratic, and exponential) to describe relationships with MAT. Model selection was carried out based on adjusted $R^{2}$ and RMSE. Dotted lines indicate best fitted lines. (c) $y=0.105 x^{2}-0.381 x+2.673, R^{2}=0.975$, $\operatorname{RMSE}=1.19,(\mathrm{e}) \mathrm{y}=0.959 \mathrm{e}^{0.031 \mathrm{x}}, R^{2}=0.664, \mathrm{RMSE}=0.186,(\mathrm{f}) \mathrm{y}=0.180 \mathrm{e}^{0.135 \mathrm{x}}, R^{2}=0.789$, RMSE $=0.486$

Fig. 2 (a) $\mathrm{C}$ and (b) $\mathrm{N}$ contents of ash in relation to percentage of bryophyte cover. (a) $\mathrm{y}=$ $0.339 \mathrm{x}+10.267, R^{2}=0.821, \mathrm{RMSE}=4.680,(\mathrm{~b}) \mathrm{y}=0.0258 \mathrm{x}+1.119, R^{2}=0.777, \mathrm{RMSE}=$ 0.409.

Fig. 3 Pool size of (a) $\mathrm{NO}_{3}{ }^{-} \mathrm{N}$, (b) $\mathrm{NH}_{4}{ }^{+}-\mathrm{N}$, and (c) inorganic $\mathrm{N}\left(\mathrm{NO}_{3}{ }^{-}-\mathrm{N}+\mathrm{NH}_{4}{ }^{+}-\mathrm{N}\right)$ of ash pots in relation to MAT. We tested three models (linear, quadratic, and exponential) to describe relationships with MAT. Model selection was carried out based on adjusted $R^{2}$ and RMSE. (b) $\mathrm{y}=-0.002 \mathrm{x}+0.144, R^{2}=0.824, \mathrm{RMSE}=0.0058$ for 2014, (c) $\mathrm{y}=-0.002 \mathrm{x}+$ $0.150, R^{2}=0.805, \mathrm{RMSE}=0.0242$ for 2014.

Fig. 4 Proportion of inorganic $\mathrm{N}$ to total $\mathrm{N}$ in ash pots in relation to MAT. Solid line, dotted line and broken line indicate the significant relationships between proportion of inorganic $\mathrm{N}$ to total $\mathrm{N}$ and MAT for $2013\left(\mathrm{y}=0.0091 \mathrm{x}+18.618, R^{2}=0.0003, \mathrm{RMSE}=3.729\right), 2014(\mathrm{y}=$ $\left.-0.3655 \mathrm{x}+13.294, R^{2}=0.9716, \mathrm{RMSE}=0.408\right)$ and $2015\left(\mathrm{y}=-1.0599 \mathrm{x}+22.866, R^{2}=\right.$ $0.8551, \mathrm{RMSE}=2.847)$, respectively 
Fig. 5 Leaching of (a-c) $\mathrm{NO}_{3}{ }^{-}-\mathrm{N}$, (d-f) $\mathrm{NH}_{4}{ }^{+}-\mathrm{N}$, and (g-i) inorganic $\mathrm{N}$ from ash pots in relation to MAT for 1-year, 2, and 3 years of experiment. We tested three models (linear, quadratic, and exponential) to describe relationships with MAT. Model selection was carried out based on adjusted $R^{2}$ and RMSE. There were no significant relationships with MAT.

Fig. 6 Gene abundance of (a-c) bacterial 16S rRNA, (d-f) archaeal 16S rRNA, and (g-i) fungal ITS for 1-year, 2, and 3 years of experiment in relation to MAT. We tested three models (linear, quadratic, and exponential) to describe relationships with MAT. Model selection was carried out based on adjusted $R^{2}$ and RMSE. Closed circle and open triangle indicate lower and upper layer of ash pots, respectively. (c) $\mathrm{y}=-0.012 \mathrm{x}^{2}+0.192 \mathrm{x}+6.838, R^{2}$ $=0.874$, RMSE $=0.156$ for Lower layer, (f) $\mathrm{y}=-0.015 \mathrm{x}^{2}+0.261 \mathrm{x}+4.285, R^{2}=0.959$, RMSE $=0.766$ for Lower layer

Fig. 7 Gene abundance of (a-c) bacterial $a m o A$ and (d-f) Archaeal $a m o A$ for 1-year, 2, and 3 years of experiment in relation to MAT. We tested three models (linear, quadratic, and exponential) to describe relationships with MAT. Model selection was carried out based on adjusted $R^{2}$ and RMSE. There were no significant relationships with MAT. Closed circle and open triangle indicate lower and upper layer of ash pots, respectively. 
Highlights Tateno et al.

- The first three years of $\mathrm{C}$ and $\mathrm{N}$ accumulation were investigated in a field mesocosm

- By 24 months, $\mathrm{C}$ and $\mathrm{N}$ accumulation did not show a clear correlation with temperature

- By 36 months, $\mathrm{C}$ and $\mathrm{N}$ accumulation correlated exponentially with temperature

- The abundance of soil microbes did not increase with time and temperature

- The faster $\mathrm{C}$ and $\mathrm{N}$ acceleration in warmer sites may relate to bryophyte cover 
Fig. 1 Tateno et al.
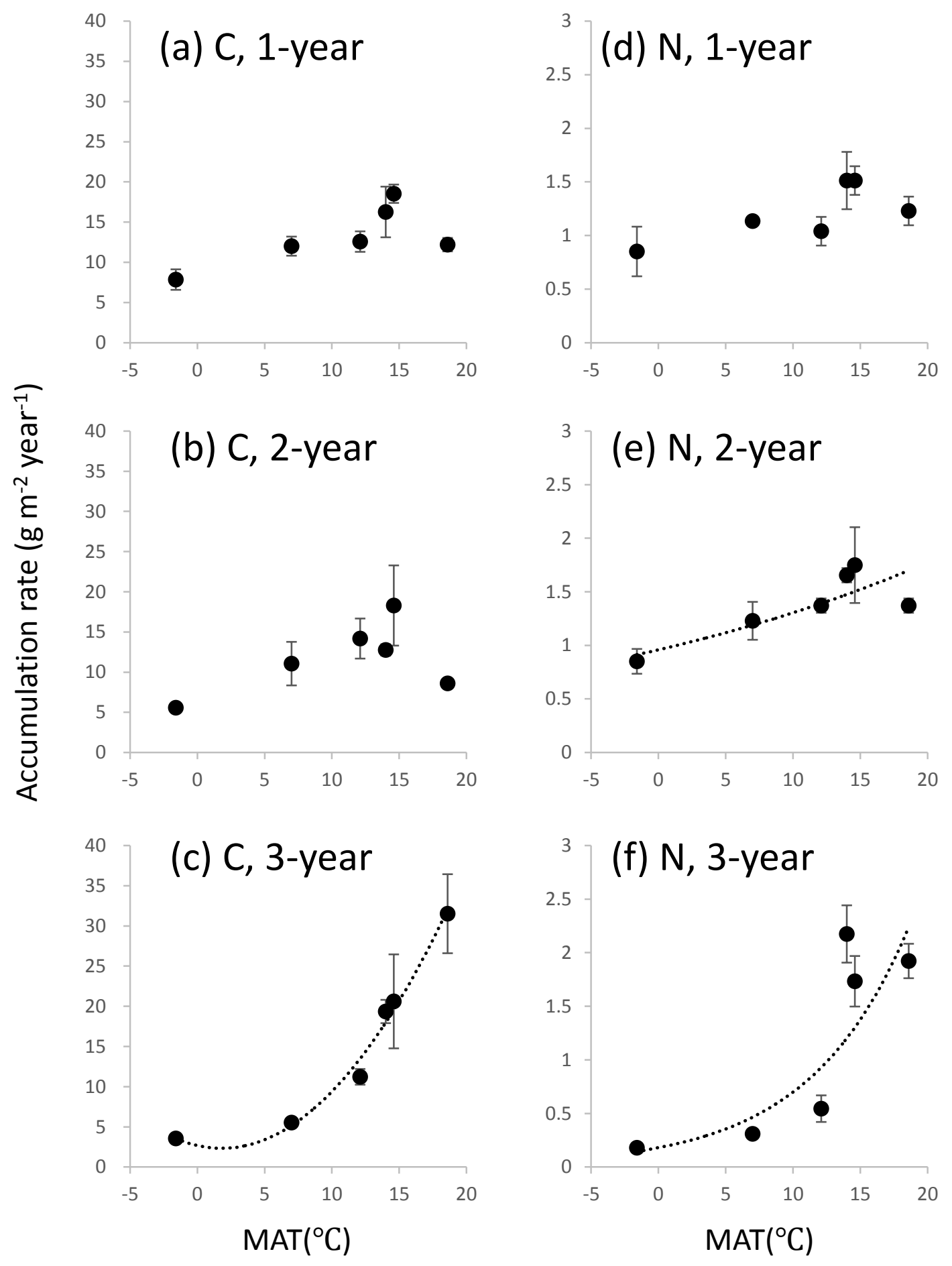
Fig. 2 Tateno et al.
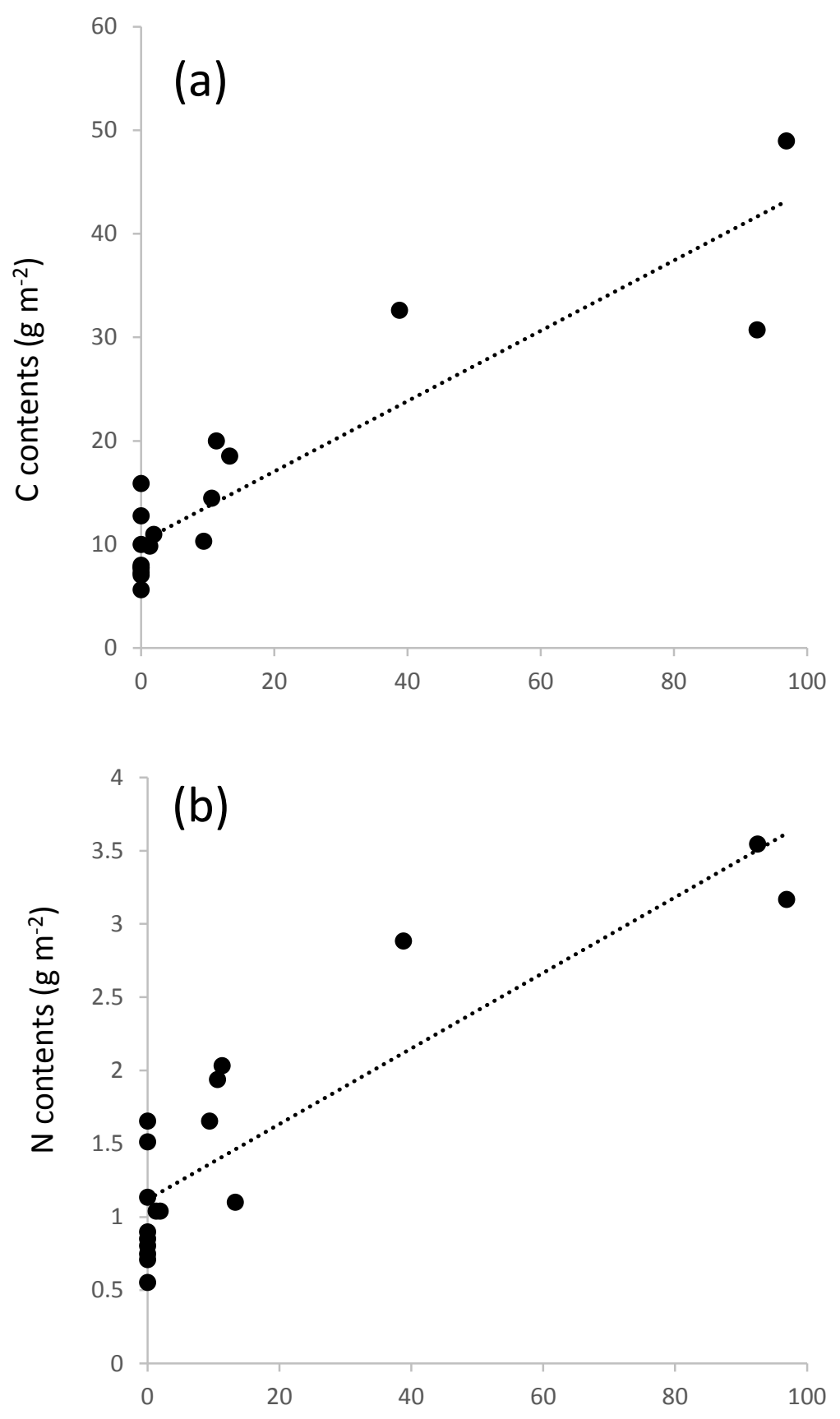

Percentage of Bryophyte cover (\%) 
Fig. 3 Tateno et al.
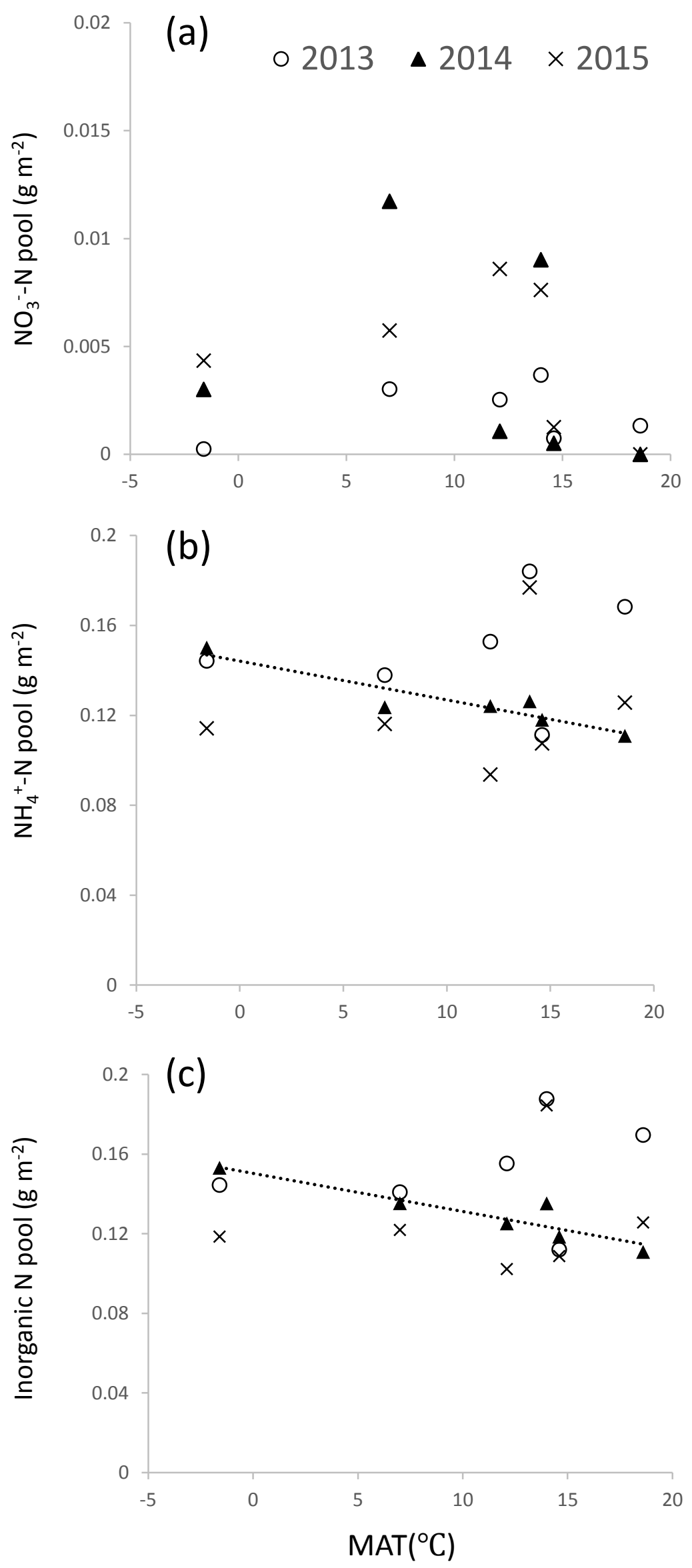
Fig. 4 Tateno et al.

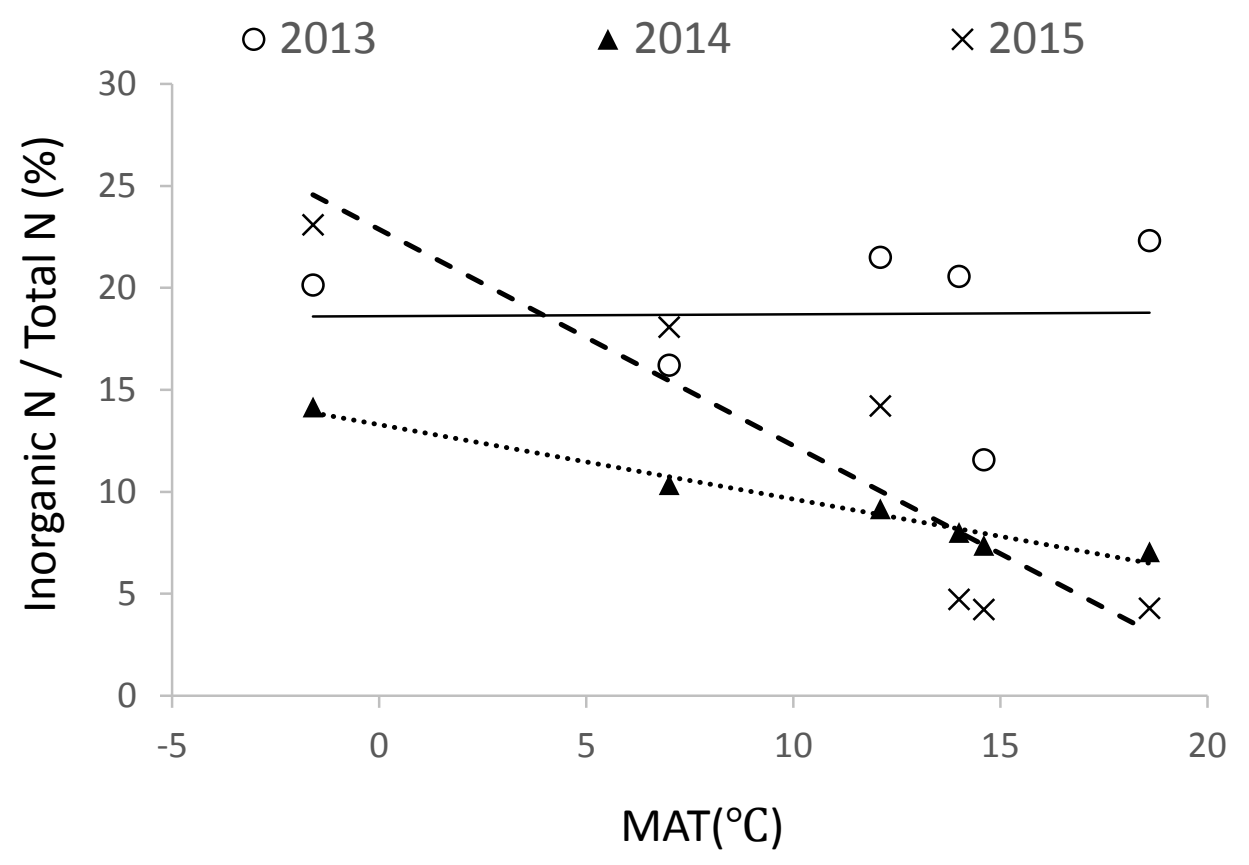


Fig. 5 Tateno et al.
(a) 1-year
(b) 2-year
(c) 3-year
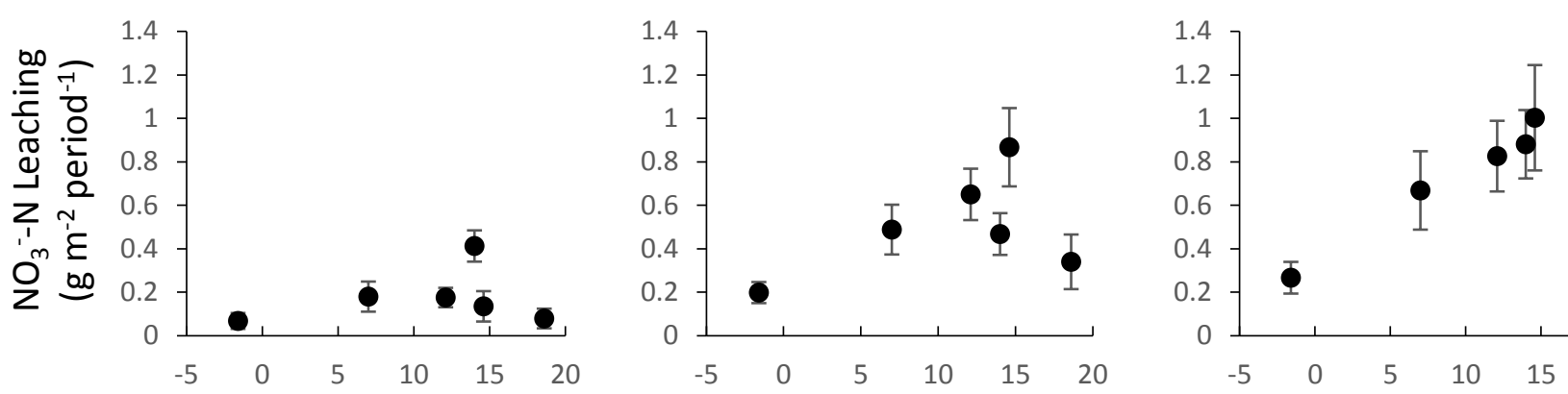

(d) 1-year

(e) 2-year
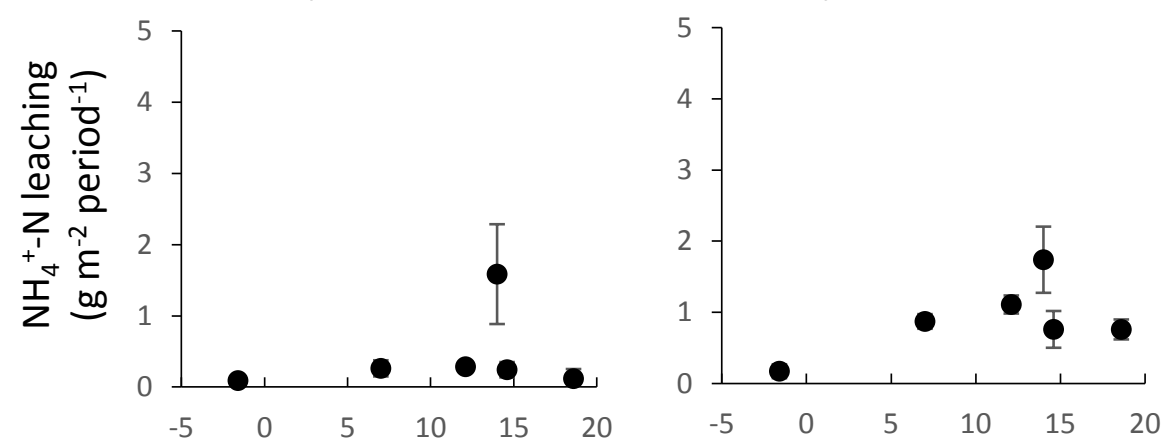

(f) 3-year

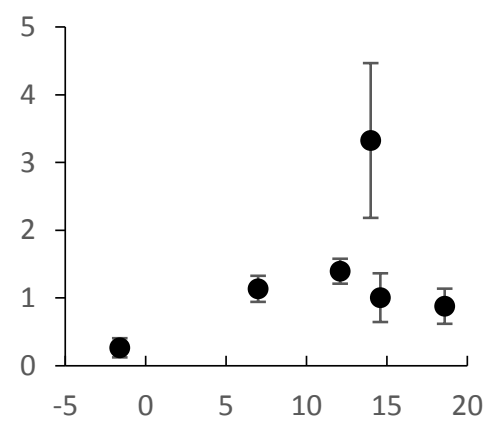

(g) 1-year

(h) 2-year

(i) 3-year
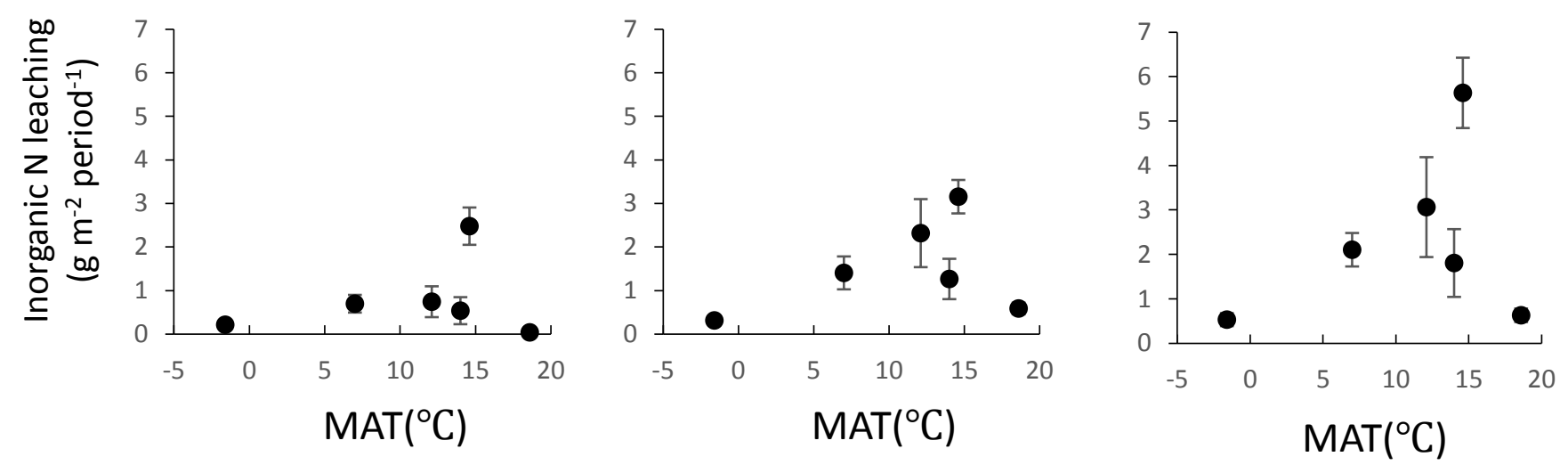
Fig. 7 Tateno et al.
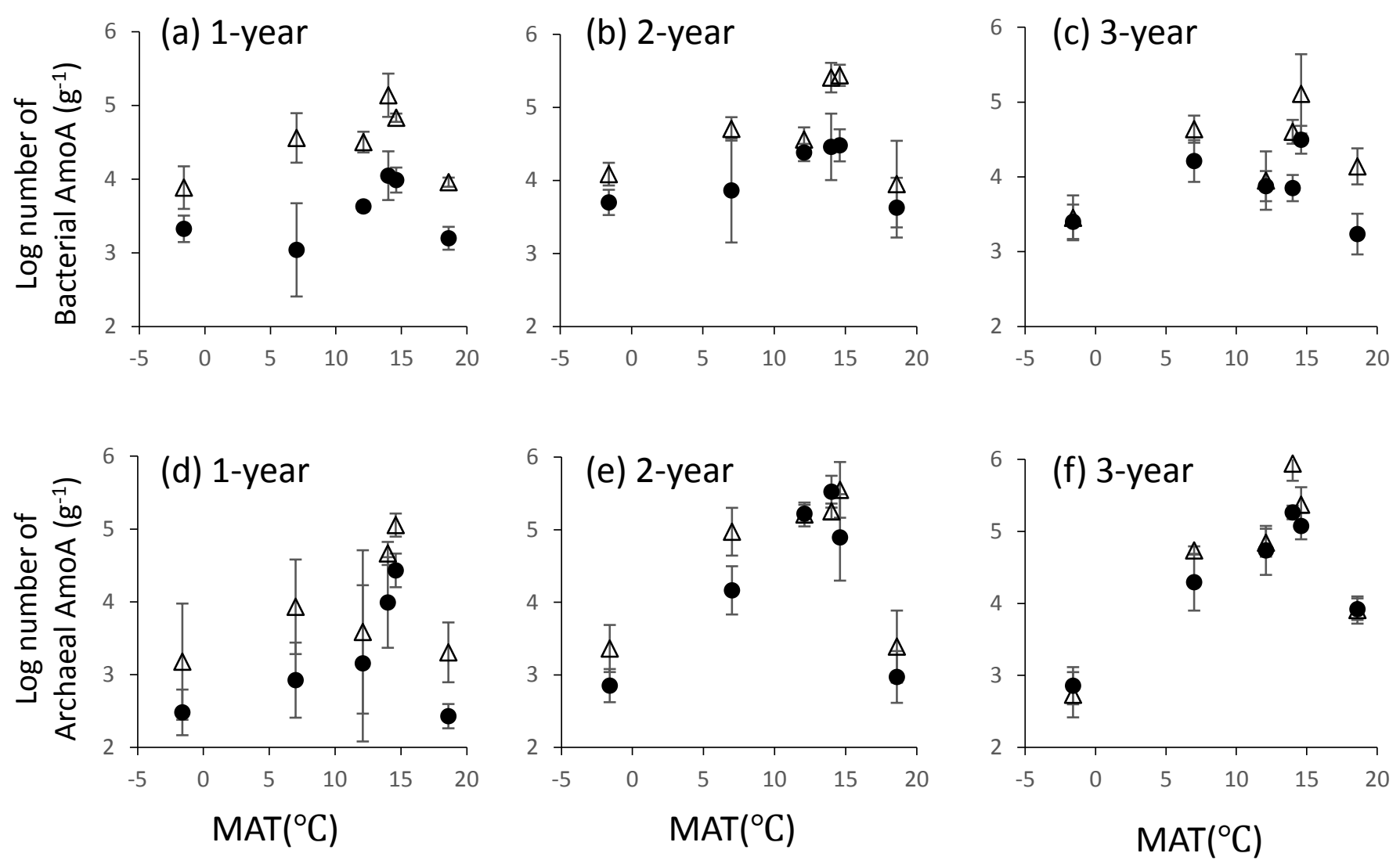